\title{
Pandemi Covid-19: Flattening The Curve, Kebijakan dan Peraturan
}

\author{
Dimas Zakaria ${ }^{1}$, Rr. Halimatu Hira ${ }^{2}$ \\ Jurusan Ilmu Hukum Universitas Lampung \\ e-mail: dimaszakaria42@gmail.com ${ }^{1}$, halimatuhira@gmail.com²
}

\begin{abstract}
Abstrak
Kurva epidemologi (epidemic curve) yang menjadi parameter untuk menangani wabah virus corona, yaitu dengan melandaikan kurva penyebaran (flatten the curve) dapat dilakukan dengan meningkatkan jumlah kesembuhan pada pasien dan pemberlakukan kebijakan dan peraturan dalam upaya membatasi jarak antar manusia. Kebijakan dan peraturan yang saat ini berlaku di Indonesia dinilai perlu diberi gagasan baru yang inovatif, jelas, dan konsisten. Melalui Flattening the Curve (FtC), dapat menjadi alternatif solusi program yang tepat dalam menangangi pandemi dengan tujuan untuk melandaikan kurva penyebaran. Program yang berisi dua substansi kebijakan, yaitu: healthy policy, program dalam rangka meningkatkan jumlah kesembuhan pasien yang terdiri atas deteksi virus berskala besar. Psychological service, pemberian layanan check up, dan expert role. Program kedua berupa pembuatan kebijakan dan peraturan (legal action) yang jelas dan konsisten untuk memberi kepastian hukum kepada masyarakat yang memperhatikan unsur-unsur kejelasan (legal substance), ketegasan (legal structure), dan peran masyarakat dalam wujud budaya hukum (legal culture). Dengan demikian, melalui program ini upaya pemerintah dalam melandaikan kurva penyebaran (flatten the curve) dapat berjalan dengan baik.
\end{abstract}

Kata Kunci :

Covid-19, Flattening The Curve, Kebijakan, Peraturan

\section{PENDAHULUAN}

Pandemi virus corona yang telah menyebar secara global menimbulkan korban jiwa yang sangat tinggi karena per Mei 2020 jumlah kematian terkonfirmasi sejumlah 330.803 jiwa. ${ }^{1}$ Hal ini menjadi

\footnotetext{
${ }^{1}$ Worldometer, "COVID-19 CORONAVIRUS PANDEMIC" dalam https://www.worldometers. info/coronavirus/diakses 21 Mei 2020 pukul 21.23 WIB.
}

tantangan berbagai negara di dunia untuk menangulangi wabah dan sesegera mungkin berusaha untuk mengakhiri pandemi ini. Kebijakan yang dibuat pemerintah memang disesuaikan dengan kondisi negaranya masing-masing, tujuannya sama, yaitu untuk menekan laju penyebaran virus agar kasus terkonfirmasi semakin berkurang dan setiap pasiennya dapat ditangani dengan baik. Parameter 
yang dapat menjadi dasar dalam memperlambat penyebaran virus adalah menggunakan kurva epidemologi.

Kurva epidemologi adalah kurva yang menggambarkan perkembangan penyakit atau suatu wabah berdasarkan waktu dan jumlah orang yang menderita penyakit tersebut. $^{2}$ Wabah yang saat ini terjadi, yaitu virus corona (Covid-19) juga dapat digambarkan melalui kurva epidemologi.

Sebenarnya, bagaimanakah tindakan yang tepat dalam menangangi virus corona berdasarkan kurva epidemologi?, langkah yang paling efektif adalah melandaikan kurva penyebaran virus atau lazim disebut flatten the curve. $^{3}$ Melandaikan kurva penyebaran virus tentu dilakukan dengan membuat peraturan dan kebijakan dalam upaya membatasi jarak antar manusia dan meningkatkan penanganan yang baik dalam upaya penyembuhan pada pasien.

Pentingnya tindakan pemerintah dalam melandaikan kurva (flatten the curve) sudah dibuktikan oleh Korea Selatan yang berhasil menanggulangi pandemi dengan tingkat kesembuhan 50.8\%. ${ }^{4}$ Indonesia

\footnotetext{
${ }^{2}$ Centers for Disaese Control and Prevention, "Interpretation of Epidemic Curve" dalam http://www.cdc.gov/foodsafety/outbreaks/investiga ting-outbreaks/epi-curves.html diakses 11 Mei 2020 pukul 6.13 WIB.

${ }^{3}$ Brandon Spector, "Coronavirus: What Is 'Flattening The Curve', and Will It Work?" dalam https://www.google.com/amp/s/www/livescience.c om/amp/coronavirus-flatten-the-curve.html, diakses 18 Mei 2020 pukul 22.14 WIB.

${ }^{4}$ Mujahidah Achiru, "4 Negara yang Memiliki Tingkat Kesembuhan Sangat Tinggi Kasus COVID-19 Melebihi Angka Kumulatif di Seluruh Dunia” dalam https://www.google.com/amp/s/
}

sebagai negara yang mengalami dampak yang besar dari pandemi virus ini memang sudah berupaya melandaikan kurva tersebut dengan memberlakukan kebijakan dan peraturan, namun beberapa di antaranya tidak jelas dan tidak konsisten. Akibatnya, pelanggaran terus terjadi dan kasus terkonfirmasi semakin meningkat walaupun bersifat fluktuatif. ${ }^{5}$

Berdasarkan latar belakang tersebut, flattening the curve (FcT) hadir sebagai program penanganan virus corona melalui upaya untuk melandaikan kurva dengan meningkatkan penanganan kesehatan bagi pasien, yaitu dengan healthy policy. Upaya tersebut juga harus diseimbangkan dengan kebijakan dan peraturan yang didasarkan pada kurva epidemologi (epidemic curve) wabah virus corona. Kebijakan dan peraturan tersebut akan memperhatikan aspek-aspek hukum tertentu, yaitu kejelasan (legal substance), ketegasan (legal structure), dan budaya (legal culture).

Oleh karena itu, tulisan ini berusaha menjawab pertanyaan bagimanakah peran kurva epidemologi (epidemic curve) dalam upaya melandaikan kurva penyebaran?. Bagaimanakah efektifitas program Flattening the Curve $(\mathrm{FtC})$ dalam aspek keseha-

mediabro.id/4-negara-yang-memiliki-tingkat-kese mbuhan-sangat-tinggi-kasus-covid-19-melebihi-an gka-kumulatif-di-seluruh-dunia/amp/ diakses 18 Mei 2020 pukul 22.20 WIB.

${ }^{5}$ Kementerian Kesehatan Republik Indonesia, "Pemantauan Kasus COVID-19 Indonesia" dalam http://www.pusatkritis.kemenkes.go.id/covid19.id/, diakses 18 Mei 2020 pukul 22.01 WIB. 
tan dan hukum?. Bagaimanakah realisasi Flattening the Curve $(\mathrm{FtC})$ di Indonesia?

\section{TINJAUAN TEORETIS}

\section{Kebijakan Sebagai Konsep}

Mengelola, mengurus, dan melayani masyarakat merupakan tugas dari pemerintah. Hal pertama yang perlu untuk dilakukan oleh pemerintah adalah membuat sebuah regulasi atau kebijakan dalam rangka menciptakan kemaslahatan masyarakat. ${ }^{6}$ Kebijakan (policy) sendiri pada umumnya ialah tindakan untuk memilih, menentukan dan menunjukkan pilihan sebagai upaya mempererat kehidupan, baik itu dalam kehidupan privat, organisasi, ataupun pemerintahan. Sebuah kebijakan harus terbebas dari nuansa politis atau keberpihakan yang diakibatkan oleh adanya sebuah kepenti-ngan.

Kebijakan berlaku dan dicirikan dengan tindakan, baik itu oleh masyarakat ataupun pembuat kebijakan yang dijalankan secara konsisten. ${ }^{7}$ Kebijakan dibedakan menjadi dua yakni, kebijakan publik dan kebijakan privat. Kebijakan publik dapat diartikan sebagai kewenangan pemerintah yang telah diberikan legitimasi oleh masyarakat sebagai upaya kolektif guna mengatur, mendorong, menghambat, atau melarang tindakan privat. Dua ciri pokok dari kebijakan publik adalah dibuat berdasarkan prosedur atau lembaga yang

\footnotetext{
${ }^{6}$ Samodra Wibawa, "Kebijakan Publik" Kuliah Umum di Fakultas Ilmu Pendidikan, Universitas Negeri Yogyakarta, 3 November 2015, h.1.

${ }^{7}$ Sahya Anggara, Kebijakan Publik (Pustaka Setia: Bandung, 2014) , h.14.
}

telah ditetapkan oleh pemerintah, serta bersifat memaksa guna mengatur tindakan-tindakan privat. $^{8}$

\section{Pandemi Covid-19}

Pandemi merupakan wabah penyakit yang telah meluas keseluruh dunia atau dalam kata lain wabah ini telah menjangkit dan menjadi permasalahan bersama masyarakat dunia. Coronavirus merupakan kelompok virus yang dapat menyebabkan penyakit infeksi saluran pernapasan pada hewan atau manusia, beberapa diantaranya diketahui dapat mengakibatkan infeksi pernapasan pada manusia seperti batuk pilek hingga ancaman yang lebih serius seperti Middle East Respiratory Syndrome (MERS) dan Severe Acute Respiratory. Covid-19 sendiri merupakan jenis coronavirus jenis baru yang pertama kali ditemukan di Wuhan, China, pada Desember 2019. Rasa lelah, demam, dan batuk kering merupakan gejala paling umum virus ini.

Orang yang memiliki penyakit sebelumnya seperti tekanan darah tinggi, gangguan jantung atau diabetes dan orang orang yang telah lanjut usia memiliki kemungkinan mengalami sakit lebih serius yang lebih besar jika terpapar virus ini. Virus ini dapat tertular dari orang lain yang tengah terjangkit.

Media penularan virus ini berasal dari kontak langsung ataupun kontak tidak langsung seperti percikan percikan dari mulut dan hidung penderita, yang

${ }^{8}$ Pantjar Simatupang, "Analisis Kebijakan : Konsep Dasar dan Prosedur Pelaksanaan", Analisis Kebijakan Pertanian, Vol. 1, No. 1 (2003), h. 2. 
kemudian disentuh oleh orang lain. Penularan juga bisa berasal dari napas yang keluar dari tubuh penderita. Oleh karena itu penting untuk disaat seperti ini melakukan pembatasan jarak dengan orang yang sakit minimal 1 meter. $^{9}$

\section{Flatten The Curve}

Flatten the curve dapat diartikan, meratakan kurva dengan mengilustrasikan bahwa perlu untuk kita berusaha mengurangi jumlah penularan yang naik secara curam. Upaya tersebut diwujudkan dengan melakukan menjaga kesehatan dan kebersihan tubuh serta meminimalisasi keluar rumah sehingga dapat mengurangi penyebaran virus. Grafik kurva akan melandai dengan berkurangnya penularan, sekalipun penularan tetap terjadi, tetapi kenaikan akan relatif lebih lamban dan mudah untuk ditangani oleh rumah sakit, dokter ataupun perawat. ${ }^{10}$

Guna menciptakan kondisi demikian, penelitian ini memberikan sebuah gagasan tentang bagaimana upaya yang dapat dilakukan oleh pemerintah dalam upaya penanganan pandemi ini dalam sudut pandang hukum dan kesehatan. Upaya pembuatan kebijakan yang efektif dan tidak bertentangan satu sama lain serta pemberlakuan sanksi sosial bagi pelanggar

\footnotetext{
${ }^{9}$ World Health Organization, "Pertanyaan dan Jawaban Terkait Coronavirus" dalam https://www.who.int/indonesia/news/novel-corona virus/qa-for-public diakses 19 Mei 2020 pukul 14.38 WIB.

${ }^{10}$ Nadhif Seto Sanubari, "'Flatten the Curve': Apa Maksudnya dan Kenapa Perlu Dilakukan" dalam https://smartcity.jakarta.go.id/blog/472/flat ten-the-curve-apa-maksudnya-dan-kenapa-perludilakukan diakses 5 Mei 2020 pukul 14.35 WIB.
}

kebijakan perlu diberlakukan oleh pemerintah sebagai solusi.

Pemerintah juga perlu untuk mengadakan pendeteksian virus secara besar menggunakan RTPCR, penyediaan pelayanan psikis bagi masyarakat, check up, serta perlu adanya peran serta dari perguruan tinggi untuk menciptakan inovasi-inovasi ventilator dalam penan-ganan pandemi ini.

\section{METODE PENELITIAN}

Penelitian ini adalah penelitian dekskriptif eksperimen yang dimaksudkan untuk memberikan masukan terhadap penanganan pandemi Covid-19. Sumber data yang didapatkan dalam penelitian ini bersumber dari data sekunder yang terdiri dari buku, jurnal, penelitian, regulasi dan kebijakan, serta berita elektronik yang berkaitan dengan penelitian ini. Penelitian disusun menggunakan metode dekriptif analitis guna memudahkan pemahaman atas penelitian ini. Guna mencapai sebuah kesimpulan penelitian ini menggunakan metode induktif dalam proses penyusunannya.

\section{PEMBAHASAN}

\section{Kurva Pelandaian dan Covid-19}

Wabah virus corona yang muncul sebagai pandemi karena sudah tersebar di sebagian besar negara di dunia. Indonesia sebagai negara yang mengalami pandemi ini secara signifikan karena dalam waktu tiga bulan jumlah penderita sudah mencapai 
18.010 jiwa. $^{11}$ Berbagai kebijakan telah diberlakukan demi mengurangi penyebaran virus yang menular dengan cepat. Kebijakan dan peraturan yang diterapkan pemerintah dalam mereduksi penyebaran virus harus menekankan pada upaya untuk memperlambat penyebaran virus atau dalam ilmu epidemologi disebut pelandaian kurva (flatten the curve). ${ }^{12}$

Flatten the curve menggambarkan usaha untuk mengurangi tingkat kecuraman naiknya jumlah penularan. Dengan demikian, grafik kurva akan semakin landai walaupun jumlah kasus akan tetap naik, kenaikan tersebut terjadi lebih lambat dan setiap kasusnya akan ditangani oleh tenaga medis dengan baik.

Gambar

Kurva Pelandaian

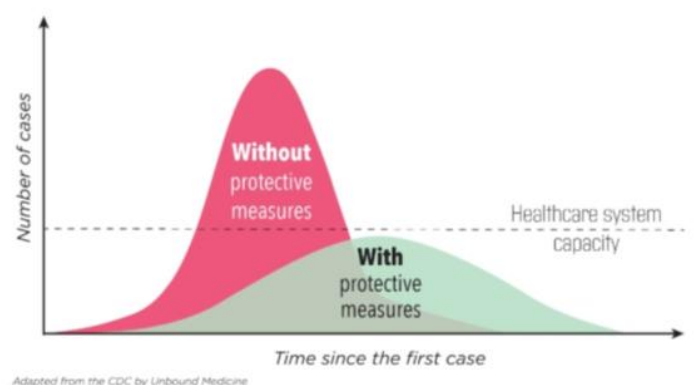

Berdasarkan kurva di atas, ${ }^{13}$ terdapat dua kurva yang menggambarkan jumlah kasus yang sama dalam periode waktu tertentu. Kurva pertama, kurva merah, meng-

\footnotetext{
${ }^{11}$ Nadhif Seto Sanubari, 5 Mei 2020.

${ }^{12}$ Brandon Spector, 18 Mei 2020.

${ }^{13}$ William M. Detmer, "Epidemic (Epi) Curves for Coronavirus COVID-19" dalam https://relief.unboundmedicine.com/relief/view/Cor onavirusGuidelines/2355041/all/Epidemic_Epi__ Curves_for_Coronavirus_COVID_19 diakses 19 Mei 2020 pukul 18.45 WIB.
}

gambarkan jumlah kasus virus korona yang meningkat drastis dalam waktu yang singkat. Akibatnya, jumlah kematian pasien tinggi, terlihat pada tinggi dan sempitnya kurva. Kurva kedua, kurva hijau, menggambarkan jumlah kasus virus corona dengan laju pertumbuhan yang lambat. Hal ini terlihat pada kurva yang rata artinya, setiap kasus dapat ditangani dengan baik walapun, dengan waktu yang lama. Faktor yang menentukan kesembuhan pasien adalah jumlah rumah sakit dan alat-alat kesehatan yang memadai, terlihat pada garis putus-putus disepanjang kurva yang rata (health care system capacity).

Upaya yang dapat ditempuh dalam melandaikan kurva berdasarkan garis putus-putus disepanjang kurva yang rata (health care system capacity) jelas dengan meningkatkan jumlah fasilitas kesehatan, namun saat ini fasilitas kesehatan di Indonesia masih belum memadai baik jumlah rumah sakit rujukan, ventilator, dan alat pelindung diri bagi tenaga medis. Hal ini berdampak pada tingkat kematian pasien per April 2020, Indonesia menjadi negara dengan jumlah kematian tertinggi di Asia Tenggara. ${ }^{14}$ Oleh karenanya, dibutuhkan penambahan jumlah fasilitas kesehatan di setiap rumah sakit dalam rangka mengurangi jumlah kematian. Alatalat kesehatan khususnya ventilator harus terus diproduksi di dalam negeri karena kemungkinan pasien yang tingkat keparahnnya sudah tinggi akan meninggal

\footnotetext{
${ }^{14}$ Bachtiarudin Alam, "Corona di Asia Tenggara: Terbanyak di Singapura, RI Angka Kematian Tertinggi" dalam https://m.merdeka .com/peristiwa/corona-di-asia-tenggara-terbanyakdi-singapura-ri-angka-kematian-tertinggi.html diakses 18 Mei 2020 pukul 23.34 WIB.
} 
tanpa ventilator. ${ }^{15}$ Selain itu, dibutuhkan pula konsep dan cara baru dalam menangani pasien agar jumlah kesembuhan pasien terus meningkat.

Selain meningkatkan fasilitas kesehatan, penerapkan kebijakan serta peraturan yang dapat membatasi jarak antar manusia diperlukan sebagai aspek yang paling penting karena kunci melandaikan kurva dengan memutus mata rantai penyebaran virus. Perlu diketahui bahwa, virus corona menyebar dari orang ke orang melalui percikan dari hidung atau mulut yang keluar dari orang yang terjangkit virus. ${ }^{16}$ Manusia yang mempunyai peran penting dalam penyebaran virus karena virus tersebut menyebar secara eksponensial, artinya apabila terdapat satu orang berstatus positif, maka ia dapat menulari rata-rata dua orang lainnya, yang dipengaruhi oleh sistem kekebalan tubuh (imunitas). ${ }^{17}$ Oleh karena itu, pemerintah harus menekankan pada kebijakan social distancing, physical distancing, dan isolasi. Kebijakan tersebut juga harus diseimbangi dengan kebiasaan masyarakat

${ }^{15}$ Seto Ajinugroho, "Sangat Membantu Pasien Corona Sembuh, Ini Kegunaan Ventilator Untuk Atasi Covid-19 yang Diminta Jokowi ke AS" dalam https://sosok.grid.id/read/412122434/sangatmem bantu-pasien-corona-sembuh-ini-kegunaanventi lator-untuk-atasi-covid-19-yang-dimintajokowi-ke-as diakses 18 Mei 2020 pukul 23.52 WIB.

${ }^{16}$ World Health Organization, 19 Mei 2020.

${ }^{17}$ National Geographic Indonesia, "Mengapa Meratakan Kurva Penularan Sangat Penting?Ini Penjelasannya" dalam https://www.google.com /amp/s/nationalgeographic.grid.id/amp/132084314/ mengapa-meratakan-kurva-penularan-sangatpenting-ini-penjelasannya diakses 6 Mei 2020, pukul 04.35 WIB. dalam menjaga kebersihan seperti, menggunakan hand sanitizer, mencuci tangan dengan sabun, dan menggunakan masker saat berada di luar rumah. ${ }^{18}$

Beberapa negara yang membuat kebijakan berdasarkan kurva epidemologi (epidemic curve) dan berhasil meratakan penyebaran virus sebelum infeksi virus melonjak tajam adalah Taiwan, yaitu dengan menetapkan kebijakan dengan tepat setelah wabah virus di Wuhan, China, muncul dan merespon cepat setiap kasus yang terkonfirmasi sehingga jumlah kematian sangat rendah. ${ }^{19}$ Korea Selatan juga berhasil meratakan kurva penyebaran virus dengan cepat tanpa lockdown dengan jumlah penduduk yang tinggi mereka melakukan rapid test dengan skala besar. Hal tersebut berakibat dengan jumlah kematian pasien yang rendah dan cepatnya setiap kasus ditangani. Berdasarkan keberhasilan negara-negara tersebut menangangi virus corona, kita tahu akan pentingnya melandaikan kurva epidemologi (epidemic curve) dengan kebijakan dan peraturan yang jelas, namun di Indonesia belum bisa merealisasikan kebijakan ataupun peraturan yang jelas dan konsisten.

Hal ini dibuktikan dengan diterapkannya peraturan menteri perhubungan tentang

\footnotetext{
${ }^{18}$ World Health Organization, 19 Mei 2020.

${ }^{19}$ Raden Trimutia Hatta, "Kisah Sukses 7 Negara Menekan Penyebaran Virus Corona COVID-19" dalam https://m.liputan6.com/global/ read/4220610/kisah-sukses-7-negara-menekanpenyebaran-virus-corona-covid-19 diakses 19 Mei 2020 pukul 14.29 WIB.
} 
larangan mudik lebaran. ${ }^{20}$ Per 23 April 2020 pemerintah menetapkan seluruh masyarakat dilarang untuk mudik lebaran tanpa pertimbangan apapun, sedangkan pemerintah melalui Menteri Koordinator Bidang Kemaritiman dan Investasi memperbolehkan masyarakat untuk mudik dengan protokol kesehatan tertentu. ${ }^{21}$

Kebijakan tersebut dinilai tidak konsisten dan masyarakat bingung akan kejelasan peraturan yang dibuat. Kondisi ini diperparah dengan penetapan sanksi yang baru diberlakukan 8 - 31 Mei 2020 (15 hari setelah diberlakukannya peraturan). ${ }^{22}$ Hal demikian membuat terjadinya peluang untuk melanggar aturan karena penerapan sanksi yang lambat. Oleh karena itu, dalam pembuatan peraturan pemerintah harus memperhatikan kejelasan peraturan (legal substance) yang berdasarkan kurva epidemologi (epidemic curve) untuk mencapai kurva yang landai (flatten the curve).

${ }^{20}$ Kementerian Perhubungan RI. "Peraturan Menteri Perhubungan Republik Indonesia No. 25 Tahun 2020 Tentang Pengendalian Transportasi Selama Musim Mudik Idul Fitri $1441 \mathrm{H}$ dalam Rangka Pencegahan Penyebaran Covid-19" dalam http://jdih.dephub.go.id/assets/uudocs/permen/2020 /PM_25_TAHUN_2020.pdf diakses 18 Mei 2020 pukul 23.00 WIB.

${ }^{21}$ Dian Riski Rosmayanti, Ahmad Reza S, dan Solichin M. Awi, "Protocol Mudik Dimatangkan" dalam http://m.harnas.co/2020/04/03/protokolmudik-dimatangkan diakses 19 Mei 2020 pukul 12.53 WIB.

${ }^{22}$ INDONESIA.GO.ID, "Ketentuan Larangan Mudik dan Pembatasan Transportasi" dalam https://indonesia.go.id/layanan/kependudukan/ekon omi/ketentuan-larangan-mudik-dan-pembatasantransportasi diakses 19 Mei 2020 pukul 12.40 WIB.
Setelah peraturan dibuat berdasarkan kurva epidemologi (epidemic curve) harus disesuaikan dengan ketegasan aparat penegak hukum baik dalam memberlakukan peraturan dan pemberian sanksi (legal structure), dan peran masyarakat sebagai wujud dari budaya hukum (legal culture). Dengan demikian, peraturan dan kebijakan pemerintah yang dibuat berdasarkan kurva epidemologi (epidemic curve) dan bertujuan untuk melandaikan laju penye-baran virus akan jelas dan konsisten serta dapat ditaati dengan baik oleh masyarakat.

Upaya pemerintah dalam aspek kesehatan berupa meningkatkan jumlah kesembuhan pada pasien serta kebijakan dan peraturan untuk menekan laju penyebaran virus corona telah dikaji dalam Flattening the Curve (FtC). Program ini diharapkan dapat melandaikan kurva penyebaran berdasarkan kebijakan dan peraturan dalam bentuk legal action. Selain itu, meningkatkan kesembuhan pasien berupa kebijakan healthy policy, yang penerapannya melalui kerjasama berbagai pihak terkait.

\section{Flattening The Curve (FtC)}

Flattening the Curve (FtC) merupakan program yang dapat dijadikan gagasan bagi pemerintah dalam upaya melandaikan kurva penyebaran (flatten the curve). Program ini sangat menekankan usaha untuk meningkatkan jumlah kesembuhan pada pasien berupa healthy policy dan kebijakan serta peraturan yang jelas dan konsisten berupa legal action.

Program ini dibuat berdasarkan komparasi dari berbagai negara dan disesuaikan 
dengan kondisi masyarakat Indonesia saat ini. Pemerintah, otoritas terkait, dan masyarakat menjadi unsur terpenting dalam substansi program ini, dengan kerjasama dan koordinasi yang baik dan sesuai prosedur.

\section{Health Policy}

Upaya pemerintah dalam penanganan virus corona memang sudah terlihat dalam pemberlakuan Pembatasan Sosial Berskala Besar (PSBB), yang berisi anjuran untuk isolasi mandiri dengan meliburkan sekolah dan tempat kerja, serta membatasi kegiatan yang menimbulkan terjadinya kerumunan. ${ }^{23}$ Hal ini dilakukan agar dapat menekan laju penyebaran virus yang sampai saat ini terus meningkat walaupun bersifat fluktuatif. ${ }^{24}$

Penyebaran virus yang sangat cepat dan waktu sakit yang bersamaan memang menjadi permasalahan yang paling esensial dalam penanganan wabah ini. Kondisi ini diperparah dengan fasilitas kesehatan di Indonesia yang belum memadai, hal ini berakibat pada jumlah kematian pada pasien yang tinggi, yaitu sekitar 1.191 jiwa, sedangkan jumlah kesembuhan pasien 4.324 jiwa dari 18.010 kasus terkonfirmasi. ${ }^{25}$ Tingkat kesembuhan

\footnotetext{
${ }^{23}$ Republik Indonesia, "Peraturan Pemerintah Republik Indonesia No. 21 Tahun 2020 Tentang Pembatasan Sosial Berskala Besar dalam Rangka Percepatan Penanganan Corona Virus Disease 2019 (COVID-19)" dalam https://jdih. setkab.go.id/PUUdoc/176085/PP_Nomor_21_Tahu n_2020.pdf diakses 19 Mei 2020 pukul 12.00 WIB.

${ }^{24}$ Kementerian Kesehatan Republik Indonesia, 19 Mei 2020.

${ }^{25}$ Kementerian Kesehatan Republik Indonesia, 19 Mei 2020.
}

pasien dipengaruhi oleh pendeteksian adanya virus dengan cepat, jumlah virus yang masuk ke dalam tubuh, dan imunitas atau kekebalan tubuh. ${ }^{26}$ Oleh karena itu, dibutuhkan program baru yang dapat menekan jumlah kematian dan meningkatkan jumlah kesembuhan pada pasien di Indonesia. Melalui program healthy policy terdapat program dalam aspek kesehatan yang terdiri atas deteksi virus berskala besar, psychological service, pemberian layanan check up, dan expert role.

\section{a. Deteksi Virus Berskala Besar}

Pendeteksian virus corona secara umum berfungsi untuk mengetahui secara dini paparan virus yang terkandung dalam tubuh manusia. Indonesia sendiri melakukan pendeteksian virus melalui melalui dua metode, yaitu melalui Reverse Transcription Polymerase Chain Reaction (RTPCR) dan Rapid test. World Health Organization (WHO) memberikan penegasan bahwa, Reverse Transcription Polymerase Chain Reaction (RTPCR) merupakan standar utama dalam pemeriksaan virus corona, yaitu dengan mengambil cairan saluran pernapasan $\left(\right.$ swab) yang dinilai lebih akurat. ${ }^{27}$ Hal ini

\footnotetext{
${ }^{26}$ Raja Eben Lumbanrau, "Virus corona: Gejala Covid-19, Penyebaran, penanganan, pengobatan, dan penyembuhan" dalam https://www.google.com/amp/s/www.bbc.com/ind onesia/amp/indonesia-51232803, diakses 19 Mei 2020 pukul 14.50 WIB.

${ }^{27}$ CNN Indonesia, "WHO Tak Sarankan RI Deteksi Kasus Corona Lewat Rapid Test" dalam https://m.cnnindonesia.com/internasional/2020042 1160400-106-495752/who-tak-sarankan-ri-deteksikasus-corona-lewat-rapid-test diakses 15 Mei 2020 pukul 12.02 WIB.
} 
sudah dibuktikan oleh negara Malaysia yang mengandalkan Reverse Transcription Polymerase Chain Reaction (RTPCR) dalam pendeteksian virus dengan kasus yang cukup tinggi (6.941 kasus), namun jumlah kematian sangat rendah (113 kematian). ${ }^{28}$

Pemerintah Indonesia sendiri telah menggalakan program pedeteksian virus corona secara masal dengan metode Rapid Test, yaitu dengan menggunakan sampel darah untuk mendeteksi antibodi IgM dan $\mathrm{IgG},{ }^{29}$ yang dibentuk oleh tubuh apabila ada paparan virus. ${ }^{30}$ Rapid test secara tingkat keakuratannya memang belum terlalu tinggi karena masih diperlukan Reverse Transcription Polymerase Chain Reaction (RTPCR) untuk memastikan hasilnya. $^{31}$

Pendeteksian virus yang paling akurat memang sudah jelas menggunakan Reverse Transcription Polymerase Chain Reaction (RTPCR) oleh karena itu,

\footnotetext{
${ }^{28}$ Worldometer, "World/Countries/Malaysia" dalam https://www.worldometers.info/coronavirus /country/malaysia/ diakses 19 Mei 2020 Pukul 11.23 WIB.

${ }^{29}$ Antibodi IgG adalah antibodi yang melindungi tubuh dari infeksi dengan cara "mengingat" kuman yang telah dihadapi sebelumnya, sedangkan antibodi IgM adalah antibodi yang diproduksi tubuh saat pertama kali terinfeksi bakteri atau kuman. Redaksi Halodoc, "KapanWaktu Yang Tepat Untuk Lakukan Tes Imunologi" dalam https://www.halodoc.com/ kapan-waktu-yang-tepat-untuk-lakukan-tesimunologi, diakses 19 Mei 2020 pukul 14.11 WIB.

${ }^{30}$ Rumah Sakit "JIH”, "Mengenal Rapid Test Covid-19" dalam https://rsjih.co.id/readmore/ mengenal-rapid-test-covid-19, diakses 15 Mei 2020 pukul 12.19 WIB.

${ }^{31}$ Rumah Sakit “JIH”, 15 Mei 2020.
}

pemerintah saat ini perlu melakukan pendeteksian virus berskala besar dengan metode yang paling akurat. Hal ini dilakukan karena jumlah kasus yang sebenarnya kemungkinan lebih tinggi, sebab jumlah pengetesan yang rendah membuat data menjadi tidak tepat. ${ }^{32}$

Selain itu deteksi virus dengan skala yang besar berpengaruh juga pada cepatnya penanganan pasien serta mengurangi tingkat kematian pada pasien. Kondisi ini disebabkan karena salah satu faktor tingginya jumlah kematian di Indonesia karena penanganan pasien pada tingkat keparahan yang tinggi, yang disebabkan karena keterlambatan dalam pendeteksian virus. ${ }^{33}$ Dengan demikian, Reverse Trans cription Polymerase Chain Reaction (RTPCR) perlu sesegera mungkin diterapkan di Indonesia secara cepat dan menyeluruh khususnya untuk masyarakat yang menjadi orang dalam pantauan (ODP). Pendeteksian virus yang akurat diharapkan akan mempercepat penanganan pada pasien dan mengurangi tingkat kematian akibat virus corona di Indonesia.

\section{b. Psychological Service}

Psychological service merupakan program untuk pasien dalam situasi penyembuhan

${ }^{32}$ BBC News Indonesia, "Virus Corona: Jumlah Kasus Covid-19 di Seluruh dunia lampaui empat juta kasus, peneliti peringatkan jumlah sebenarnya bisa jadi lebih tinggi," dalam https://www.google.com/amp/s/www.bbc.com/ind onesia/amp/dunia-52603625, diakses 19 Mei 2020 pukul 14.18 WIB.

${ }^{33}$ Anjar Mahardhika, "3 Faktor Penyebab Kematian Corona RI Masih Tertinggi di ASEAN" dalam http://www.m.detikhealth, diakses 19 Mei 2020 pukul 08.27 WIB. 
baik untuk pasien berstatus positif dan pasien dalam pengawasan (PDP). Program ini berisi pemberian edukasi psikis bagi pasien, hal ini dilakukan karena sebagian penderita virus corona mengalami masalah psikis stress bahkan, ada beberapa pasien yang mencoba bunuh diri. ${ }^{34}$ Hal demikian terjadi karena stigma masyarakat yang kurang baik terhadap penderita virus corona. Demikian juga berpengaruh terhadap proses kesembuhan pasien karena apabila pasien stress maka, waktu penyembuhan akan lebih lama. Oleh karena itu, layanan kesehatan berupa psychological service sangat penting dalam proses penangan pasien, yang dilakukan oleh ahli psikologi atas kerjasama dengan rumah sakit rujukan penanganan virus corona. Layanan tersebut dapat berupa konsultasi, terapi, dan motivasi agar pasien tidak stress atau bahkan bunuh diri karena perlu diingat wabah virus corona yang mereka derita bisa disembuhkan.

\section{c. Check Up}

Pemberian layanan check up kesehatan bertujuan agar mencegah korban tertular virus kedua kalinya karena pasien yang telah sembuh memiliki kemungkinan untuk terjangkit virus kembali, yang dibuktikan oleh $10 \%$ pasien virus corona di Wuhan, China, kembali terinfeksi virus

\footnotetext{
${ }^{34}$ BBC Indonesia, "Corona Serang Kejiwaan: Teriak-teriak, Serang Petugas dan Coba Bunuh Diri" dalam https://m.detik.com/news/bbc-world/d5008470/corona-serang-kejiwaan-teriak-teriakserang-petugas-dan-coba-bunuh-diri, diakses 16 Mei 2020 pukul 12.23 WIB.
}

setelah dinyatakan sembuh. ${ }^{35}$ Hal ini terjadi kemungkinan karena permasalahan sistem kekebalan tubuh ataupun mutasi virus. ${ }^{36}$ Oleh karena itu, agar tidak terjadi infeksi virus untuk kedua kalinya dibutuhkan program berupa layanan check up, bagi penderita virus corona di Indonesia yang telah dinyatakan sembuh. Layanan ini harus segera diterapkan agar peluang seseorang terinfeksi virus kembali akan segera teratasi. Setiap rumah sakit rujukan, rumah sakit umum, dan puskesmas diharapkan dapat bekerjasama untuk menerapkan layanan ini.

Pasien yang telah sembuh dari virus corona dan akan melakukan layanan check up juga harus diberikan arahan agar mengisolasikan diri di rumah (isolasi mandiri) selama beberapa hari agar apabila ada kemungkinan terinfeksi virus kembali, seseorang tersebut tidak menularkannya ke orang lain dengan alasan sudah dinyatakan sembuh. Diperlukan pula pembuatan prosedur sebagai acuan untuk menjalankan program check up ini. Dengan demikian, usaha preventif (pencegahan) terhadap pasien akan kemungkinan terinfeksi virus corona kedua kalinya akan berjalan dengan baik.

\section{d. Expert Role}

Program ini merupakan kerjasama perguruan tinggi dan otoritas terkait

\footnotetext{
${ }^{35}$ Nafillah Sri Sagita K, "Mungkinkah Seseorang Terinfeksi Virus Corona Dua Kali?" dalam https://m.detik.com/health/berita-detik health/d-4961369/mungkinkah-seseorang-terinfeksi -virus-corona-dua-kali, diakses 17 Mei 2020 pukul 20.21 WIB.

${ }^{36}$ Nafillah Sri Sagita K, 17 Mei 2020.
} 
penanganan virus corona untuk membuat program kerja secara kompleks dalam pembuatan ventilator. Ventilator merupakan alat yang berfungsi untuk menunjang atau membantu pernapasan bagi pasien yang sulit bernapas secara mandiri. ${ }^{37}$ Pasien dengan penderita virus corona akan mengalami gagal napas yang akibatnya harus menggunakan ventilator agar bisa bertahan hidup. ${ }^{38}$ Oleh karena itu, fungsi ventilator dalam proses penyembuhan virus corona sangat penting dan dibutuhkan dalam jumlah yang banyak. Perlu diketahui bahwa, di Indonesia jumlah penderita bronkitis akut sekitar 4,5\% populasi. $^{39}$ Akibatnya, apabila pasien tersebut sudah memiliki penyakit penyerta maka, tingkat keparahan akan semakin tinggi.

Ventilator yang memiliki peran penting diharapkan dapat diproduksi di dalam negeri oleh otoritas terkait dengan kerjasama perguruan tinggi di setiap provinsi di Indonesia. Institut Teknologi Bandung (ITB) misalnya sebagai salah satu contoh perguruan tinggi yang telah

${ }^{37}$ Michael Kevin Robby Setyana, "Mengenal Ventilator, Manfaat, dan Kekurangannya" dalam https://www.alodokter.com/mengenal-ventilatormanfaat-dan-kekurangannya, diakses 17 Mei 2020 pukul 18.56 WIB

${ }^{38}$ Esti Widiyana, "Dokter Paru Sebut Ventilator Tak Sebabkan Pasien Corona Meninggal" dalam https://m.detik.com/news/ berita-jawa-timur/d-4977241/dokter-paru-sebutventilator-tak-sebabkan-pasien-corona-meninggal, diakses 17 Mei 2020 pukul 19.34 WIB.

39 Maria Chindyvita Darung, "Kenali Bronkitis dan Pencegahannya" dalam https://inilah.com/rileks/ 2302714/kenali-bronkitisdan-pencegahannya, diakses 23 Mei 2020 pukul 14.45 WIB. berhasil membuat ventilator untuk membantu tenaga medis dalam menangani pasien. ${ }^{40}$ Langkah perguruan tinggi yang telah ikut serta dalam menghasilkan ventilator produksi dalam negeri, dapat dilakukan pula di berbagai perguruan tinggi di setiap provinsi di Indonesia tentunya, dengan koordinasi berbagai institusi terkait serta pemerintah dapat memberikan dana yang cukup. Dengan demikian, ventilator akan banyak dihasilkan dan pasien penderita virus corona akan terbantu dengan alat tersebut. Akibatnya, jumlah pasien yang sembuh akan terus meningkat.

\section{Legal Action}

Upaya dalam menekan jumlah kematian memang telah dikaji dalam healthy policy, namun untuk mencapai kurva penyebaran yang landai (flatten the curve) diperlukan pula kebijakan dan peraturan yang tepat dan konsisten. Kebijakan dan peraturan tersebut terdapat dalam legal action, yang berisi kebijakan untuk memberikan kepastian hukum dalam masyarakat, serta memperhatikan unsur-unsur berhasil tidaknya penegakkan hukum. ${ }^{41}$ Legal action sendiri terdiri atas 3 substansi kebijakan yaitu:

\footnotetext{
${ }^{40}$ Vivanews, "Inovasi Berbasis Teknologi dari Indonesia Untuk Hadapi Virus Corona" dalam https://www.vivanews.com/berita/nasional/49311inovasi-berbasis-teknologi-dari-indonesia-untukhadapi-virus-corona, diakses 17 Mei 2020 pukul 20.03 WIB.

${ }^{41}$ Rocky Marbun, "Grand Design Politik Hukum Pidana dan Sistem Hukum Pidana Indonesia Berdasarkan Pancasila dan UndangUndang Dasar Negara Republik Indonesia 1945", Padjajaran Jurnal Ilmu Hukum, Vol.1, No.3 (2014), h.4.
} 
a. Legal Substance

Kejelasan peraturan (legal substance), substansi hukum atau aspek kejelasan peraturan adalah norma, aturan, dan perilaku masyarakat yang di dalamnya terdapat "produk", sebuah keputusan yang pembuatannya berdasarkan peristiwa terlebih dahulu. Pembuatan produk peraturan berdasarkan pandemi virus corona telah tertuang dalam berbagai regulasi, antara lain: Peraturan Menteri Kesehatan Nomor 9 Tahun 2020 Tentang Pedoman Pembatasan Sosial Berskala Besar dalam Rangka Percepatan Penanganan Corona Virus Disease 2019, Peraturan Pemerintah (PP) Nomor 21 Tahun 2020 Tentang Pembatasan Sosial Berskala Besar dalam Rangka Percepatan Penanganan Corona Virus Disease 2019 (Covid-19), dan Peraturan Menteri Perhubungan Nomor 25 Tahun 2020 Tentang Pengendalian Transportasi Selama Musim Mudik Idul Fitri 1441 H dalam Rangka Pencegahan Penyebaran Covid-19. Regulasi tersebut memang sudah ditujukan untuk menangani wabah virus corona, namun beberapa peraturan masih belum ada kejelasan secara substansinya.

Salah satu regulasi yang dibuat pemerintah dalam mengurangi jumlah penderita virus corona dimuat dalam peraturan pemerintah dalam mengurangi jumlah penularan virus, yang sudah ditetapkan berdasarkan peraturan menteri perhubungan mengenai pembatasan keluar masuknya masyarakat antar wilayah (mudik lebaran) hingga 31 Mei 2020, namun belum memiliki kepastian yang jelas. Hal ini dibuktikan dengan dibukanya penerbangan khusus domestik per 3 Mei untuk pebisnis ${ }^{42}$ dan diperbolehkannya masyarakat dengan kriteria tertentu, dari luar negeri masuk ke Indonesia. $^{43}$ Peraturan tersebut memang diberlakukan karena Indonesia belum merapkan kebijakan karantina wilayah, namun pemerintah harus konsisten dengan usaha untuk melandaikan kurva (flatten the curve) yang artinya, walaupun ada kriteria tertentu untuk bermobilitas, namun mereka punya peluang untuk tertular dan menulari virus dengan orang lain bahkan, dapat menciptakan kluster baru penyebaran virus.

Hal ini semakin diperparah dengan pemberlakuan sanksi pidana dan uang Rp 100 Juta bagi pelanggar mudik lebaran yang baru diberlakukan 8 - 31 Mei 2020, sedangkan Peraturan Menteri sudah berlaku tanggal 24 April 2020. ${ }^{44}$ Kondisi tersebut membuat masyarakat bingung dan tidak mengerti akan regulasi yang diberlakukan pemerintah. Oleh karena itu, legal action dapat digunakan sebagai gagasan baru dalam pembuatan substasi

${ }^{42}$ Tira Santia, "Mulai 3 Mei, Lion Air Layani Penerbangan Rute Domestik dengan Izin Khusus" dalam https://m.liputan6.com/bisnis/read/4240065/ mulai-3-mei-lion-air-layani-penerbangan-rute-

domestik-dengan-izin-khusus, diakses 19 Mei 2020 pukul 12.23 WIB.

${ }^{43}$ Kementerian Kesehatan RI, "Surat Edaran Menteri Kesehatan Nomor HK.02.01/Menkes 1313/2020 Tentang Protokol Kesehatan Penanganan Kepulangan WNI dan Kedatangan WNA dari Luar Negeri di Pintu Masuk Negara dan Wilayah pada Situasi Pembatasan Sosial Berskala Besar (PSBB)" dalam https://covid19.go.id/p/ protokol/surat-edaran-menteri-kesehatan-nomorhk0201menkes31320 20 dikases 19 Mei 2020 pukul 13.00 WIB.

${ }^{44}$ INDONESIA.GO.ID, 19 Mei 2020. 
peraturan yang jelas dengan penerapan sanksi yang konsisten.

Kebijakan legal action kejelasan peraturan (legal substance) terletak pada pembuatan peraturan yang ditujukan kepada masyarakat yang berdasarkan kurva epidemologi (epidemic curve), yang ber-tujuan untuk melandaikan kurva (flatten the curve). Basis substansi peratur-an serta penetapan sanksi juga diperlukan beracuan pada kurva epide-mologi (epidemic curve) dan sanksi yang bersifat sosial dan bermanfaat di tengah pandemi saat ini. Berdasarkan data per Mei 2020 jumlah kasus terkonfirmasi sebanyak 18.010 kasus. Jumlah tersebut selalu berubah-ubah dari hari ke hari. ${ }^{45}$

Kenaikan jumlah kasus per harinya walaupun sifatnya fluktuatif harus menjadi acuan bagi pemerintah untuk membuat kebijakan. Artinya, semua kebijakan harus tetap bertujuan melandaikan kurva penyebaran (flatten the curve) dengan pembatasan sosial berskala besar (PSBB), pemerintah benar-benar melarang adanya aktivitas masyarakat keluar dari rumahnya. Memberlakukan kebijakan dalam satu keluarga apabila ingin membeli kebutuhan sehari-hari hanya diperuntukan untuk satu orang yang dapat keluar dari rumah.

Sanksi yang diberlakukan apabila masyarakat tidak menaatinya dapat berupa sanksi sosial, yaitu pemberdayaan pembuatan masker kain dan alat pelindung diri (APD)

\footnotetext{
${ }^{45}$ Kementerian Kesehatan Republik Indonesia, 18 Mei 2020.
}

untuk tenaga medis. Hal tersebut dapat efektif sebagai sanksi karena walapun pemerintah menerapkan sanksi pidana ataupun denda, masyarakat tetap melanggar dan kembali mengulangi perbuatannya. Setidaknya kegiatan sosial berupa pemberdayaan masyarakat dapat menjadi solusi yang paling efektif dalam penerapan sanksi di situasi pembatasan sosial berskala besar dan kegiatan tersebut bermanfaat bagi tenaga medis yang sedang menangani pasien virus corona saat ini.

\section{b. Legal Structure}

Ketegasan aparat penegak hukum (legal structure), merupakan sistem struktural yang dijadikan sebagai penentu bisa atau tidaknya hukum itu dilaksanakan dengan baik. $^{46}$ Peraturan yang telah dibuat pemerintah dalam situasi pandemi saat ini tidak dapat berjalan baik apabila, tidak ada aparat penegak hukum yang memiliki kredibilitas, kompeten, dan independen. Akibatnya, akan banyak terjadi pelanggaran dan sikap acuh tak acuh pada peraturan. ${ }^{47}$ Oleh karena itu, dibutuhkan kebijakan pemerintah dalam menindak tegas bagi aparat penegak hukum yang melanggar hukum dengan sanksi yang lebih tinggi dari masyarakat yang melanggar peraturan bahkan, sanksi dapat berupa pemecatan. Dengan demikian, peran aparat penegak hukum dapat benarbenar berjalan dengan baik tanpa pelanggaran apapun karena apabila aparat

46 Lawrence M. Friedmann, The Legal System: A Social Science Perspective, terjemahan M. Khozim (Bandung: Nusamedia, 2011).

${ }^{47}$ Lawrence M. Friedmann, 2011. 
penegaknya saja sudah melanggar apalagi masyarakat yang menjalankan aturan.

\section{c. Legal Culture}

Budaya hukum (legal culture) adalah keseluruhan sikap dari warga masyarakat dan sistem nilai yang ada dalam masyarakat yang akan menentukan bagaimana seharusnya suatu hukum (peraturan) berlaku dalam masyarakat. ${ }^{48}$ Sikap dan kebiasaan masyarakat yang bisa dibangun saat ini adalah sikap dan kebiasaan untuk menaati peraturan serta cerdas dalam bertindak. Jangan sampai kita melakukan tindakan yang justru berakibat fatal contohnya, dalam penutupan McD Sarinah, banyak orang yang berkumpul di tempat tersebut bahkan, beberapa di antaranya tidak menggunakan prosedur kesehatan yang ditetapkan World Health Organization (WHO). ${ }^{49}$ Apabila dilihat dampaknya, tentu akan berakibat pada bertambahnya kasus, munculnya kluster baru, dan yang paling parah adalah pandemi ini tidak kunjung berakhir. Oleh karena itu, dibutuhkan kesadaran masyarakat yang tinggi untuk disiplin terhadap segala keputusan pemerintah sebab, apapun bentuknya pemerintah sedang berupaya untuk menangani pandemi ini secepat mungkin.

Masyarakat yang disiplin terhadap segala kebijakan dan peraturan yang telah dibuat

\footnotetext{
${ }^{48}$ Lawrence M. Friedmann, 2011.

${ }^{49}$ Tim detikcom, "Kerumunan di McD Sarinah Berujung Denda Rp 10 Juta" dalam https://m.detik.com/news/berita/d-5015577/ kerumunan-di-mcd-sarinah-berujung-denda-rp-10juta diakses 19 Mei 2020 pukul 13.50 WIB.
}

pemerintah akan menciptakan keteraturan kondisi di tengah pandemi saat ini bahkan, pandemi virus ini dapat cepat berakhir. Hal ini bisa kita lihat dari masyarakat Vietnam yang benar-benar taat terhadap peraturan pemerintah pada saat lockdown yang akhirnya, pandemi dapat berakhir tanpa satupun kasus kematian. ${ }^{50}$ Apapun bentuknya baik lockdown ataupun pembatasan sosial berskala besar (PSBB) itu sama-sama upaya pemerintah sebagai solusi dari permasalahan ini. Pemerintah akan bekerja keras dalam menghadapi pandemi ini, tenaga medis akan menangani pasien dengan baik, dan kita cukup mengikuti semua arahan, taat pada peraturan, serta dapat berpikir cerdas dalam melakukan setiap tindakan.

\section{Realisasi Flattening The Curve di Indonesia}

Program Flattening the Curve (FcT) dalam upaya melandaikan kurva penyebaran virus serta menekan jumlah kematian pada pasien diharapkan sesegera mungkin direalisasikan di Indonesia. Realisasi program ini dapat dilakukan mulai akhir Mei atau awal Juni 2020 di berbagai wilayah baik yang telah berstatus zona merah (red zone) ataupun yang belum. Dibutuhkan pula kerjasama antara pemerintah dan masyarakat agar program ini terealisasi dengan sempurna. Adapun tahap realisasi dimulai dengan pengkajian lebih lanjut tentang kurva epidemologi (epidemic curve) untuk mencapai

\footnotetext{
${ }^{50}$ Worldometer, "World/Countries/Vietnam" dalam https://www.worldometers.info/coronavirus /country/viet-nam/ diakses 19 Mei 2020 Pukul 12.41 WIB.
} 
pelandaian kurva (flatten the curve), kemudian dilihat aspek kesehatan yang dapat menekan jumlah kematian pada pasien, dan yang terakhir realisasi peraturan dan kebijakan serta edukasi masyarakat tentang seluruh program tersebut.

\section{Healthty Policy}

Realisasi program healthty policy yang pertama adalah mengenai pendeteksian virus berskala besar. Pendeteksian ini akan dilakukan menggunakan Reverse Transcription Polymerase Chain Reaction (RTPCR) karena metode ini dinilai sangat akurat. Oleh karena itu, data sebenarnya tentang siapa saja yang berstatus positif akan terdeteksi dengan baik. Akibatnya, pasien-pasien tersebut akan cepat ditangani tanpa tingkat keparahan yang sudah tinggi. Pemerintah Indonesia sendiri telah melakukan tes masal baik dengan metode rapid test dan Reverse Transcription Polymerase Chain Reaction (RTPCR) di beberapa rumah sakit baik swasta maupun negeri, ${ }^{51}$ namun tempattempat yang dianggap rentan munculnya pembawa virus perlu diterapkan secara ketat contohnya, di bandara, tempat perbatasan, perkantoran yang masih aktif bekerja, dan daerah yang sudah berstatus zona merah (red zone) harus dideteksi tanpa terkecuali agar seluruh kasus dapat terdeteksi.

\footnotetext{
${ }^{51}$ Niken Widya Yunita, "Daftar Lokasi Tes Rapid Test dan PCR COVID-19" dalam https://m.detik.com/news/berita/d-5016162/daftarlokasi-tes-rapid-test-dan-pcr-covid-19, diakses 19 Mei 2020 pukul 13.33 WIB.
}

Kedua realisasi psychological service, yang dilakukan dalam proses penyembuhan pada pasien baik pasien dalam pantauan (PDP) maupun pasien yang telah berstatus positif. Layanan ini akan diterapkan dirumah sakit rujukan yang menangani virus corona melalui bantuan dari ahli-ahli psikis. Pasien dapat diberikan edukasi psikis ataupun memberikan keluhan terkait masalah psikis yang mereka rasakan. Hal ini akan meningkatkan semangat pasien untuk sembuh dari virus corona dan setelah diperbolehkan kembali ke rumah mereka tidak akan merasa khawatir tentang stigma yang muncul dari masyarakat karena semua itu telah diedukasi melalui psychological service. Dengan demikian, jumlah pasien sembuh akan bertambah apabila, layanan ini segera diterapkan dengan baik. Diperlukan pula koordinasi ahli dari Ikatan Psikologi klinis Indonesia dalam realisasi program ini agar berjalan sebagaimana mestinya. ${ }^{52}$

Ketiga realisasi ayanan Check $U p$, yang akan direalisasikan langsung berdasarkan surat keterangan dari rumah sakit pihak terkait yang berisi pernah berstatus dan dirawat di rumah sakit tersebut. Realisasi program ini sangat membutuhkan peran

${ }^{52}$ Psikologi klinis adalah bidang ilmu psikologi yang bertujuan memahami, mencegah, dan mengurangi ketidakmampuan, gangguan dan ketidaknyamanan yang menimbulkan masalah psikologis dalam penyesuaian dan perkembangan pribadi manusia. Ikatan Psikologi Klinis Indonesia, "Siapa yang Dapat Disebut Psikologi Klinis" dalam https://ipkindonesia.or.id/siapa-yang-dapat-disebutpsikolog-klinis, diakses 19 Mei 2020 pukul 13.46 WIB. 
serta dari pemerintah terkait dana, yaitu atas kerjasama dari Badan Penyelenggara Jaminan Sosial (BPJS). Kerjasama ini mengenai biaya Layanan Check $U p$ yang gratis atau tidak dipungut biaya apapun. Pihak terkait (pasien) juga diperlukan kesadarannya untuk mengikuti layanan ini setelah dinyatakan sembuh agar tidak terjadi kemungkinan tertular virus kedua kalinya ataupun penyakit lain, yang disebabkan karena kondisi kesehatan yang masih rentan terhadap penyakit. Apabila pemeritah, otoritas terkait, dan pasien dapat bekerjasama dengan baik maka, Layanan Check Up dapat direalisasikan dengan baik pula.

Keempat terkait realisasi expert role, yaitu akan direalisasikan sesegera mungkin dengan koordinasi pihak perguruan tinggi disetiap provinsi yang mampu melakukan penelitian dan pembuatan ventilator. Program ini juga harus berada di bawah kementerian kesehatan dan kementerian riset, teknologi, dan pendidikan tinggi, terkait dana dan pedoman untuk menjalankan program. Dibutuhkan pula peran serta dosen dan mahasiswa secara aktif dan inovatif agar program ini terlaksana dengan baik. Selain itu, dibutuhkan pula sosialisasi mendalam terkait prosedur program antara otoritas pemerintah, mahasiswa, dan ahli untuk menginterpretasikan secara tepat dalam pembuatan produk yang dapat digunakan dalam skala nasional. Dengan demikian, akan tercipta produk karya anak bangsa yang bermanfaat bagi penangan pandemi virus corona di Indonesia.

\section{Legal Action}

Realisasi pembuatan peraturan dan kebijakan pemerintah berupa legal action yang berdasarkan kurva epidemologi (epidemic curve) untuk mencapai kurva yang landai (flatten the curve) terdiri atas kebijakan dan peraturan yang membutuhkan peran pemerintah dan masyarakat antara lain: pertama kejelasan (legal substance), yaitu pengaplikasian peraturan dalam pembatasan sosial berskala besar (PSBB) berupa kebijakan pembatasan keluar rumah bagi masyarakat. Apabila mereka ingin keluar membeli kebutuhan dibatasi hanya satu orang sanak keluarga yang diperbolehkan keluar, dan apabila ada keperluan darurat harus mendapatkan izin dari aparat setempat. Realisasi dari kebijakan ini diperlukan peran aparat penegak hukum yang sangat signifikan baik dalam jalannya peraturan maupun sanksi yang berupa pemberdayaan pembuatan masker dan alat pelindung diri (APD). Dibutuhkan tempat yang sesuai prosedur kesehatan untuk menjalankan sanksi sosial tersebut. Hal yang paling penting adalah sosialisasi pemerintah dalam masyarakat yang bisa melalui siaran televisi, radio, ataupun media massa lainnya.

Kedua ketegasan aparat penegak hukum (legal structure), yaitu dapat direalisasikan dengan kebijakan pemerintah dalam menindak tegas aparat penegak hukum yang melanggar peraturan dengan sanksi yang paling tinggi berupa pemecatan. Tahap realisasi yang paling penting berupa sosialisasi khusus bagi aparat penegak hukum di Indonesia agar bekerja secara 
professional dan benar-benar mengerti akan pentingnya ketegasan mereka dalam mengatur serta memberlakukan peraturan yang diterapkan pemerintah. Dengan demikian, tidak ada lagi kasus-kasus pelanggaran oleh penegak hukum dan yang paling penting masyarakat akan taat peraturan karena aparat penegak hukum yang tegas.

Ketiga budaya hukum (legal culture), yang dapat diterapkan melalui kebiasaan masyarakat dalam merespon situasi dan kebijakan yang diberlakukan pemerintah. Indikator keberhasilan suatu peraturan dan aparat penegak hukum, tanpa masyarakat yang taat akan sia-sia. Apabila masyarakat dapat benar-benar menjalankan aturan pasti laju pertambahan kasus akan berkurang, penderita akan segera sembuh karena tenaga medis akan fokus pada jumlah pasien yang tidak terlalu banyak, serta pandemi yang sudah berdampak luas ini segera berakhir. Oleh karena itu, kerjasama antara pemerintah, aparat penegak hukum, tenaga medis, dan masyarakat harus konsisten dan berjalan dengan apa yang diharapkan.

\section{KESIMPULAN}

Upaya pemerintah dalam melandaikan kurva penyebaran virus (flatten the curve) harus berupaya untuk meningkatkan tingkat kesembuhan pasien dan pembuatan peraturan dalam membatasi jarak antar manusia. Kebijakan pembatasan sosial berskala besar (PSBB) dan larangan mudik lebaran memang sudah diterapkan di Indonesia, namun masih banyak yang perlu diperbaiki dan dikembangkan. Program Flattening the Curve (FtC) Dapat menjadi gagasan inovatif bagi pemerintah dalam aspek kesehatan dan hukum (peraturan). Program ini harus segera direalisasikan di Indonesia mulai akhir Mei atau awal Juni 2020 dengan kerjasama antara pemerintah, otoritas terkait, dan peran masyarakat.

Program Flattening the Curve (FtC) berisi dua substansi kebijakan pertama, healthy policy merupakan program dalam aspek kesehatan yang bertujuan untuk meningkatkan kesembuhan pasien, yang terdiri atas deteksi virus berskala besar menggunakan metode yang paling akurat, psychological service bagi pasien yang masih dalam perawatan, Pemberian layanan check up bagi pasien yang telah dinyatakan sembuh, dan expert role sebagai program pembuatan ventilator produksi dalam negeri. Program kedua berupa peraturan pemerintah berupa legal action, yang bertujuan memberikan kepastian hukum yang jelas dan konsisten kepada masyarakat dengan memperhatikan kejelasan peraturan yang dibuat (legal substance), ketegasan aparat penegak hukum (legal structure), dan peran masyarakat sebagai wujud dari budaya hukum (legal culture).

$* * *$

\section{DAFTAR PUSTAKA}

Lawrence M. Friedmann, The Legal System: A Social Science Perspective, 
terjemahan M. Khozim (Bandung: Nusamedia, 2011).

Pantjar Simatupang, "Analisis Kebijakan : Konsep Dasar dan Prosedur Pelaksanaan", Analisis Kebijakan Pertanian, Vol. 1, No. 1 (2003).

Rocky Marbun, "Grand Design Politik Hukum Pidana dan Sistem Hukum Pidana Indonesia Berdasarkan Pancasila dan Undang-Undang Dasar Negara Republik Indonesia 1945", Padjajaran Jurnal Ilmu Hukum, Vol.1, No.3 (2014).

Sahya Anggara, Kebijakan Publik (Pustaka Setia: Bandung, 2014).

Samodra Wibawa, "Kebijakan Publik" Kuliah Umum di Fakultas Ilmu Pendidikan, Universitas Negeri Yogyakarta, 3 November 2015.

\section{Website}

Anjar Mahardhika, "3 Faktor Penyebab Kematian Corona RI Masih Tertinggi di ASEAN" dalam http://www. m.detikhealth, diakses 19 Mei 2020 pukul 08.27 WIB.

Bachtiarudin Alam, "Corona di Asia Tenggara: Terbanyak di Singapura, RI Angka Kematian Tertinggi” dalam https://m.merdeka .com/peristiwa/coro na-di-asia-tenggara-terbanyak-di-sing apura-ri-angka-kematian-tertinggi.

html diakses 18 Mei 2020 pukul 23.34 WIB.

BBC News Indonesia, "Virus Corona: Jumlah Kasus Covid-19 di Seluruh dunia lampaui empat juta kasus, peneliti peringatkan jumlah sebenarnya bisa jadi lebih tinggi," dalam https://www.google.com/ amp/s/www.bbc.com/indonesia/amp/d unia-52603625, diakses 19 Mei 2020 pukul 14.18 WIB.

Brandon Spector, "Coronavirus: What Is 'Flattening The Curve', and Will It Work?" dalam https://www.google. com/amp/s/www/livescience.com/am $\mathrm{p} /$ coronavirus-flatten-the-curve.html, diak- ses 18 Mei 2020 pukul 22.14 WIB.

Centers for Disaese Control and Prevention, "Interpretation of Epidemic Curve" dalam http://www. cdc.gov/foodsafety/outbreaks/investig ating-outbreaks/epi-curves.html diakses 11 Mei 2020 pukul 6.13 WIB.

CNN Indonesia, "WHO Tak Sarankan RI Deteksi Kasus Corona Lewat Rapid Test" dalam https://m.cnnindonesia. com/internasional/20200421160400106-495752/who-tak-sarankan-ri-dete ksi-kasus-corona-lewat-rapid-test diakses 15 Mei 2020 pukul 12.02 WIB.

Detik.com, "Corona Serang Kejiwaan: Teriak-teriak, Serang Petugas dan Coba Bunuh Diri” dalam https://m.detik.com/news/bbc-world/d -5008470/corona-serang-kejiwaan-ter iak-teriak-serang-petugas-dan-coba-b unuh-diri, diakses 16 Mei 2020 pukul 12.23 WIB.

Detik.com, "Kerumunan di McD Sarinah Berujung Denda Rp 10 Juta" dalam https://m.detik.com/news/berita/d-501 5577/ kerumunan-di-mcd-sarinah-ber ujung-denda-rp-10-juta, diakses 19 Mei 2020 pukul 13.50 WIB. 
Dian Riski Rosmayanti, Ahmad Reza S, dan Solichin M. Awi, "Protocol Mudik Dimatangkan" dalam http://m. harnas.co/2020/04/03/protokol-mudik -dimatangkan diakses 19 Mei 2020 pukul 12.53 WIB.

Esti Widiyana, "Dokter Paru Sebut Ventilator Tak Sebabkan Pasien Corona Meninggal" dalam https://m .detik.com/news/ berita-jawa-timur/d4977241/dokter-paru-sebut-ventilatortak-sebabkan-pasien-coronameninggal, diakses 17 Mei 2020 pukul 19.34 WIB.

Ikatan Psikologi Klinis Indonesia, "Siapa yang Dapat Disebut Psikologi Klinis" dalam https://ipkindonesia.or.id/siapayang-dapat-disebut-psikolog-klinis, diakses 19 Mei 2020 pukul 13.46 WIB.

\section{INDONESIA.GO.ID,}

"Ketentuan Larangan Mudik dan Pembatasan Transportasi" dalam https://indonesia. go.id/layanan/kependudukan/ekonomi /ketentuan-larangan-mudik-dan-pemb atasan-transportasi diakses 19 Mei 2020 pukul 12.40 WIB.

Kementerian Kesehatan RI, "Pemantauan Kasus COVID-19 Indonesia" dalam http://www.pusatkritis.kemenkes.go.i d/covid19.id/, diakses 18 Mei 2020 pukul 22.01 WIB.

Kementerian Kesehatan RI, "Surat Edaran Menteri Kesehatan Nomor HK.02.01/Menkes/313/2020 Tentang Protokol Kesehatan Penanganan Kepulangan WNI dan Kedatangan WNA dari Luar Negeri di Pintu Masuk Negara dan Wilayah pada Situasi Pembatasan Sosial Berskala
Besar (PSBB)" dalam https://covid 19.go.id/p/protokol/surat-edaran-ment eri-kesehatan-nomor-hk0201menkes3 132020 dikases 19 Mei 2020 pukul $13.00 \mathrm{WIB}$.

Kementerian Perhubungan RI. "Peraturan Menteri Perhubungan Republik Indonesia No. 25 Tahun 2020 Tentang Pengendalian Transportasi Selama Musim Mudik Idul Fitri $1441 \mathrm{H}$ dalam Rangka Pencegahan Penyebaran Covid-19" dalam http://jdih.dephub.go.id/assets/uudocs/ permen/2020/PM_25_TAHUN_2020. pdf diakses 18 Mei 2020 pukul 23.00 WIB.

Maria Chindyvita Darung, "Kenali Bronkitis dan Pencegahannya" dalam https://inilah.com/rileks/ 2302714/ken ali-bronkitis-dan-pencegahannya, diakses 23 Mei 2020 pukul 14.45 WIB.

Michael Kevin Robby Setyana, "Mengenal Ventilator, Manfaat, dan Kekurangannya" dalam https://www.alodokter.com/mengenalventilator-manfaat-dankekurangannya, diakses 17 Mei 2020 pukul 18.56 WIB

Mujahidah Achiru, "4 Negara yang Memiliki Tingkat Kesembuhan Sangat Tinggi Kasus COVID-19 Melebihi Angka Kumulatif di Seluruh Dunia" dalam https://www.google. com/amp/s/mediabro.id/4-negara-yan g-memiliki-tingkat-kesembuhan-sang at-tinggi-kasus-covid-19-melebihi-an gka-kumulatif-di-seluruh-dunia/a mp/ diakses 18 Mei 2020 pukul 22.20 WIB. 
Nadhif Seto Sanubari, "Flatten the Curve': Apa Maksudnya dan Kenapa Perlu Dilakukan" dalam https:// smartcity.jakarta.go.id/blog/472/flat ten-the-curve-apa-maksudnya-dankenapa-perlu-dilakukan diakses 5 Mei 2020 pukul 14.35 WIB.

Nafillah Sri Sagita K, "Mungkinkah Seseorang Terinfeksi Virus Corona Dua Kali?" dalam https://m.detik.com/health/berita-detik health/d-4961369/mungkinkah-seseor ang-terinfeksi -virus-corona-dua-kali, diakses 17 Mei 2020 pukul 20.21 WIB.

National Geographic Indonesia, "Mengapa Meratakan Kurva Penularan Sangat Penting?Ini Penjelasannya" dalam https://www.google.com /amp/s/nationalgeographic.grid.id/ amp/132084314/mengapa-meratakankurva-penularan-sangat-penting-inipenjelasannya diakses 6 Mei 2020, pukul 04.35 WIB.

Niken Widya Yunita, "Daftar Lokasi Tes Rapid Test dan PCR COVID-19" dalam https://m.detik.com/news/berita /d-501 6162/daftar-lokasi-tes-rapidtest-dan-pcr-covid-19, diakses 19 Mei 2020 pukul 13.33 WIB.

Raden Trimutia Hatta, "Kisah Sukses 7 Negara Menekan Penyebaran Virus Corona COVID-19" dalam https: //m.liputan6.com/global/ read/4220 610/kisah-sukses-7-negara-menekanpenyebaran-virus-corona-covid-19 diakses 19 Mei 2020 pukul 14.29 WIB.

Raja Eben Lumbanrau, "Virus corona: Gejala Covid-19, Penyebaran, penanganan, pengobatan, dan penyembuhan" dalam https://www. google.com/amp/s/www.bbc.com/ind onesia/amp/indonesia-51232803, diakses 19 Mei 2020 pukul 14.50 WIB.

Redaksi Halodoc, "KapanWaktu Yang Tepat Untuk Lakukan Tes Imunologi” dalam https://www.halodoc.com/ kapan-waktu-yang-tepat-untuk-lakuka n-tes-imunologi, diakses 19 Mei 2020 pukul 14.11 WIB.

Republik Indonesia, "Peraturan Pemerintah Republik Indonesia No. 21 Tahun 2020 Tentang Pembatasan Sosial Berskala Besar dalam Rangka Percepatan Penanganan Corona Virus Disease 2019 (COVID-19)" dalam https://jdih. setkab.go.id/PUUdoc /176085/PP_Nomor_21_Tahun_2020. pdf diakses 19 Mei 2020 pukul 12.00 WIB.

Rumah Sakit "JIH", "Mengenal Rapid Test Covid-19" dalam https://rsjih.co.id/readmore/mengenal-rapidtest-covid-19, diakses 15 Mei 2020 pukul 12.19 WIB.

Seto Ajinugroho, "Sangat Membantu Pasien Corona Sembuh, Ini Kegunaan Ventilator Untuk Atasi Covid-19 yang Diminta Jokowi ke AS" dalam https://sosok.grid.id/read/412122434/s angat-mem bantu-pasien-coronasembuh-ini-kegunaan-venti latoruntuk-atasi-covid-19-yang-dimintajokowi-ke-as diakses 18 Mei 2020 pukul 23.52 WIB.

Tira Santia, "Mulai 3 Mei, Lion Air Layani Penerbangan Rute Domestik dengan Izin Khusus" dalam 
https://m.liputan6.com/bisnis/read/424 0065/ mulai-3-mei-lion-air-layani-pen erbangan-rute-domestik-dengan-izinkhusus, diakses 19 Mei 2020 pukul 12.23 WIB.

Vivanews, "Inovasi Berbasis Teknologi dari Indonesia Untuk Hadapi Virus Corona" dalam https://www.viva news.com/berita/nasional/49311-inov asi-berbasis-teknologi-dari-indonesiauntuk-hadapi-virus-corona, diakses 17 Mei 2020 pukul 20.03 WIB.

William M. Detmer, "Epidemic (Epi) Curves for Coronavirus COVID-19" dalam https://relief.unboundmedicine .com/relief/view/CoronavirusGuidelin es/2355041/all/Epidemic_Epi_Curv es_for_Coronavirus_COVID_19

diakses 19 Mei 2020 pukul 18.45 WIB.

World Health Organization, "Pertanyaan dan Jawaban Terkait Coronavirus" dalam https://www.who.int/indonesia /news/novel-corona virus/qa-forpublic diakses 19 Mei 2020 pukul 14.38 WIB.

\section{Worldometer, "COVID-19 CORONA} VIRUS PANDEMIC" dalam https://www.worldometers. info/coro navirus/ diakses 21 Mei 2020 pukul 21.23 WIB.

Worldometer,"World/Countries/Malaysia" dalam https://www.worldo meters. info/coronavirus /country/ malaysia/ diakses 19 Mei 2020 Pukul 11.23 WIB.

Worldometer, "World/Countries/Vietnam" dalam https://www.worldometers.info /coronavirus/country/viet-nam/, diakses 19 Mei 2020 Pukul 12.41 WIB. 